\title{
Patiëntenvoorlichting
}

\section{PV 27. Witte sponsnaevus}

Een witte sponsnaevus is een onschuldige afwijking van het mondslijmvlies. Er treedt daarbij sterke verhoorning van het mondslijmvlies op. Daardoor ontstaan witte veranderingen van voornamelijk het wangslijmvlies, maar soms ook van het slijmvlies op andere plaatsen in de mond, zoals dat van de tong. Slijmvliezen op andere plaatsen van het lichaam, bij voorbeeld de neus of de slokdarm, zijn meestal niet bij de afwijking betrokken.

Witte sponsnaevus is een nogal zeldzame erfelijke aandoening, die meestal al op kinderleeftijd zichtbaar is en voor de rest van het leven onveranderd aanwezig blijft. De aandoening veroorzaakt geen klachten, is niet besmettelijk en er is geen risico op kwaadaardig worden.

Meestal kan de diagnose "witte sponsnaevus" met het blote oog worden gesteld. Omdat de afwijking nogal zeldzaam is, wordt deze echter niet altijd direct door tandartsen, huisartsen of zelfs specialisten op mondheelkundig gebied herkend. Om die reden willen sommige de diagnose laten bevestigen door een klein weefselstukje uit de afwijking weg te nemen voor onderzoek door de patholoog.

Het heeft geen zin, en er is ook geen enkele noodzaak, om het wit veranderde slijmvlies te verwijderen, op welke manier dan ook. De afwijking zal steeds weer terugkomen.

\section{Wat kunt u zelf doen?}

U kunt bij een witte sponsnaevus zelf niets doen. Gelukkig gaat de afwijking niet met pijn of irritatie gepaard en is er geen zorg voor besmettelijkheid of toekomstige kwaadaardige verandering. Het is zelfs niet nodig de afwijking regelmatig door de tandarts of mondhygiënist te laten controleren.
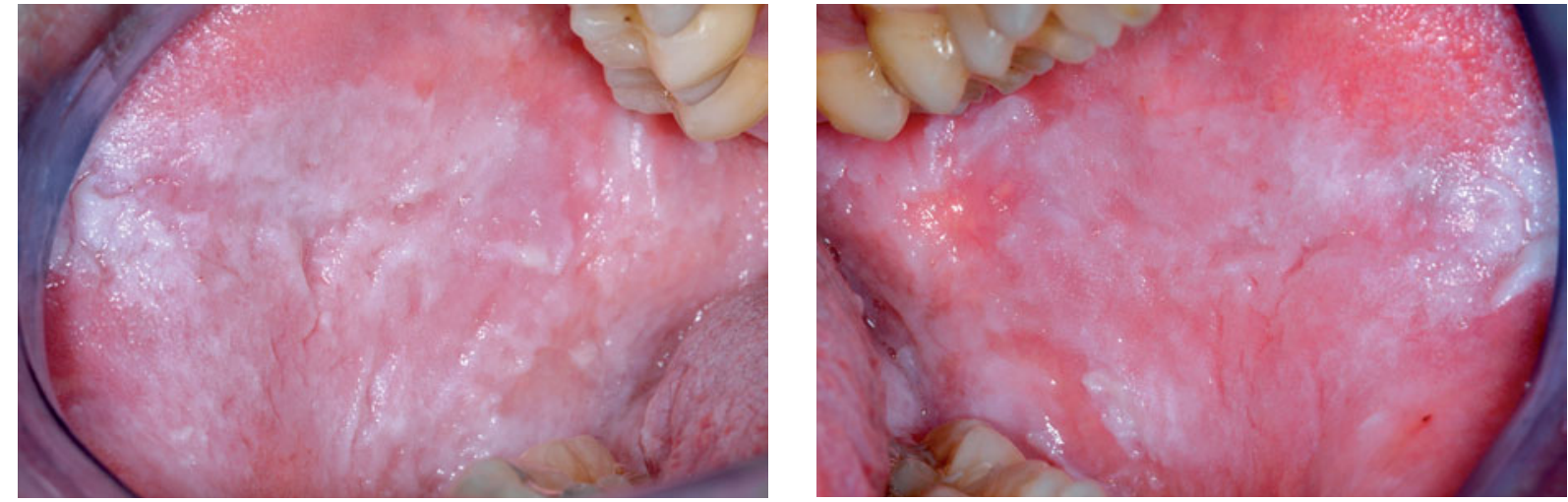